\title{
Investigation of Mental Toughness Levels of Individuals Who Actively Do Sports: A Sample of the City of Elazig
}

\author{
Yakup Kilic $^{1} \&$ Eyyup Yildirim ${ }^{1}$ \\ ${ }^{1}$ Faculty of Sports Sciences, Firat University, Elazig, Turkey \\ Correspondence: Yakup Kilic, Faculty of Sports Sciences, Firat University, Elazig, 23100, Turkey. E-mail: \\ yakupkilic@firat.edu.tr
}

Received: January 20, 2020

Accepted: February 25, 2020 Online Published: March 1, 2020

doi:10.5539/jel.v9n2p160

URL: https://doi.org/10.5539/jel.v9n2p160

\begin{abstract}
The aim of this study is to investigate the mental toughness levels of individuals who actively do sports in the face of events they face during sportive performances. Mental toughness is among the psychological characteristics to achieve the highest performance by athletes and coaches. Mental toughness is also important in terms of evaluating the performances of athletes and support their development. The population of the study consisted of individuals who actively do sports in the city of Elazig while the sample of the study consisted of 156 active athletes, who were chosen by the simple random sampling method. As the data collection tools, the personal information form, which was created by the researchers, and the Mental Toughness Scale (MTS), which was developed by Madrigal et al. (2013) and adapted into Turkish by Nevzat Erdogan by 2016, were used. In conclusion, of the athletes who participated in the study, it was observed that male athletes had higher levels of mental toughness compared to female athletes according to the gender variable. Furthermore, no significant differences were observed in terms of the variables of marital status, age, educational status, sports experience and sports branch.
\end{abstract}

Keywords: mental toughness, athlete, sport

\section{Introduction}

Humankind, in the face of negative circumstances, can generally adapt to life-changing situations in time by experiencing negative emotional states and events that result in stress. The most important element of this adaptation is the concept of mental toughness, which is a continuous process, in addition to spending time and making the effort for situations that demand individuals to take certain steps (Luthar et al., 2000). Mental toughness is regarded as a personality trait that reduces the effects of stress at the first phase and supports adaptation (Jacelon, 1997).

In a study conducted by Jones, the question, "What is this thing called mental toughness?", was investigated by focus group and individual interviews and it was concluded that the definition of mental toughness covered both general and specific dimensions. Furthermore, the definition included various attributes such as focus, self-belief, motivation and desire as well as performance, lifestyle-related elements and dealing with concepts such as pressure, anxiety, pain and hardship.

For the last forty years, mental toughness has been investigated by scientists and sports psychologists. It was stated that the most apparent features of successful performance include physical well-being, skill, experience and mental toughness while it was expressed that these elements work together during a performance (Bull et al., 2005). In another study conducted by Thelwell et al., it was attempted to define and understand the concept of mental toughness. In the study, it was noted that the concept of mental toughness does not only cover athletes but also the managers, coaches and even other professionals involved in sports, such as sport psychology consultants. It was concluded that these aspects of mental toughness should be investigated further to contribute to the overall benefit of all parties concerned (Thelwell et al., 2005).

Goldberg noted that athletes without mental toughness could be mentally insufficient and uncontrolled during performances (Goldberg, 1992). In another study, Cox reported that mental toughness was a significant factor among the qualities that are required in elite athletes (Cox, 2012). In addition to the studies conducted on mental toughness mentioned above, scientific studies have been conducted to determine the conceptual framework of 
mental toughness for the last fifteen years (Clough et al., 2002). Selk emphasized the importance of mental training in a three-step mental training program and stated that the mental training program can benefit both amateur and professional athletes in addition to coaches and parents (Selk, 2008).

Although researchers have not agreed on a clearer conceptual framework as a result of these studies, several conceptual definitions in the literature receive more emphasis. Jones et al. defined mental toughness as "in the most general sense, it is the ability of athletes to challenge their opponents in competitions, trainings and some other criteria in terms of their mental requirements while in a specific sense, mental toughness is the natural or developed psychological power of athletes to focus on their duties more than their opponents, to be more confident and under control, and to maintain these" (Jones et al., 2007). Gould et al. defined mental toughness differently. Gould et al. in their study conducted on Olympic champions and their perceptions, defined mental toughness with a wider framework that included concepts such as perseverance, indomitableness and obstinateness (Gould et al., 2002).

Clough et al. defined mental toughness as "the feeling of having an unshakable feeling of controlling one's destiny" (Clough et al., 2002). At the same time, they stated that individuals with this feeling may not be relatively affected by competition and adversities (Clough et al., 2002).

In the study conducted by Gucciardi et al. with coaches who had coaching and athletics experiences at an elite level in Australia, mental toughness was defined as "the total of the values, attitudes, behaviors and emotions that enable individuals to maintain their concentration and motivation in the face of any obstacle, difficulty or pressure as well as while things are going well to achieve aims" (Gucciardi et al., 2008). Moreover, several researchers stated that they believed mental toughness had a conceptual framework that covered other psychological features that affect sportive performance (Butt et al., 2010).

In a Ph.D. thesis conducted by Altintas, the researcher investigated mental toughness in sports in a sample that consisted of athletes from various sports branches. As a result of the study, it was concluded that mental toughness was significantly related to intrinsic and extrinsic motivations in addition to the sense of duty and emotional state (Altintas, 2015).

The aim of this study is to investigate the mental toughness of individuals who actively do sports in the face of events they face during sportive performances.

\section{Material and Method}

The aim of this study is to investigate the mental toughness of individuals who actively do sports in the face of events they face during sportive performances.

\subsection{Population and Sample of the Study}

The population of the study consisted of individuals who actively do sports in the city of Elazig while the sample of the study consisted of 156 active athletes, who were chosen by the simple random sampling method.

\subsection{Data Collection Tools}

As the data collection tools, the personal information form, which was created by the researchers, and the Mental Toughness Scale (MTS), which was developed by Madrigal et al. and adapted into Turkish by Nevzat Erdogan, were used (Madrigal et al., 2013; Erdogan, 2016). The scale is measured by a 5-point Likert scale and includes 11 items. The validity and reliability study of the scale was conducted by Erdogan and the internal consistency alpha coefficient was calculated as 0.86 (Erdogan, 2016).

\subsection{Data Analysis}

The obtained data were analyzed by using the appropriate statistical analysis method in SPSS 24 statistics software. In the statistical analyses, frequency and percentage calculations were calculated while t-test, one of the parametric tests, was conducted for two samples while variance analysis (ANOVA), another parametric test, was conducted for more than two samples. The level of significance in the study was regarded as $p<0.05$. 


\section{Results}

Table 1. Demographic information

\begin{tabular}{|c|c|c|c|}
\hline \multirow[t]{3}{*}{ Gender } & Female & 56 & 35.9 \\
\hline & Male & 100 & 64.1 \\
\hline & Total & 156 & 100.0 \\
\hline \multirow[t]{3}{*}{ Marital Status } & Married & 17 & 10.9 \\
\hline & Single & 139 & 89.1 \\
\hline & Total & 156 & 100.0 \\
\hline \multirow[t]{5}{*}{ Age } & $16-20$ & 47 & 30.1 \\
\hline & $21-25$ & 76 & 48.7 \\
\hline & $26-30$ & 22 & 14.1 \\
\hline & 31 and above & 11 & 7.1 \\
\hline & Total & 156 & 100.0 \\
\hline \multirow[t]{4}{*}{ Educational status } & High School & 33 & 21.2 \\
\hline & Undergraduate & 108 & 69.2 \\
\hline & Graduate & 15 & 9.6 \\
\hline & Total & 156 & 100.0 \\
\hline \multirow[t]{5}{*}{ Sports experience } & $1-5$ years & 10 & 6.4 \\
\hline & $6-10$ years & 9 & 5.8 \\
\hline & $11-15$ years & 34 & 21.8 \\
\hline & 16 years and above & 103 & 66.0 \\
\hline & Total & 156 & 100.0 \\
\hline \multirow[t]{3}{*}{ Sports branch } & Individual sports & 90 & 57.7 \\
\hline & Team sports & 66 & 42.3 \\
\hline & Total & 156 & 100.0 \\
\hline
\end{tabular}

Within the scope of the study, it was determined that the participating athletes, who practiced individual and team sports, included $100(64.1 \%)$ male athletes and 56 (35.9\%) female athletes. It was also determined that 48.1\% of the participants were between 21 and 25 years old while $69.2 \%$ of them had undergraduate degrees in addition to $57.7 \%$ of the athletes who were interested in individual sports.

Table 2. Results of t-test conducted with series mean according to gender

\begin{tabular}{llllllll}
\hline & Gender & N & Mean & Std. Deviation & Std. Error Mean & F & p \\
\hline \multirow{2}{*}{ Series Mean } & Female & 56 & 2.284 & 0.515 & 0.068 & 5.418 & $\mathbf{0 . 0 2 1}$ \\
& Male & 100 & 2.375 & 0.402 & 0.040 & & \\
\hline
\end{tabular}

According to the participants' results of the t-test conducted with series mean in Table 2, it was determined that there was a statistically significant difference in terms of gender $(p<0.05)$. It was also determined that this difference was more dominant in favor of males.

Table 3. Results of t-test conducted with series mean according to marital status

\begin{tabular}{llllllll}
\hline & Marital Status & $\mathbf{N}$ & Mean & Std. Deviation & Std. Error Mean & F & p \\
\hline \multirow{2}{*}{ Series Mean } & Married & 17 & 2.443 & 0.353 & 0.085 & 1.912 & 0.169 \\
& Single & 139 & 2.330 & 0.456 & 0.038 & & \\
\hline
\end{tabular}

According to the participants' results of the t-test conducted with series mean in Table 3, no statistically significant difference was observed in terms of marital status.

Table 4. Results of ANOVA test conducted with series mean according to age

\begin{tabular}{llllll}
\hline Series Mean - Age & Sum of Squares & df & Mean Square & F & Sig. \\
\hline Between Groups & 0.779 & 3 & 0.260 & 1.306 & 0.274 \\
Within Groups & 30.194 & 152 & 0.199 & & \\
Total & 30.973 & 155 & & & \\
\hline
\end{tabular}


According to the participants' results of the ANOVA test conducted with series mean in Table 4, no statistically significant difference was observed in terms of age.

Table 5. Results of ANOVA test conducted with series mean according to educational status

\begin{tabular}{llllll}
\hline Series Mean - Educational Status & Sum of Squares & df & Mean Square & F & Sig. \\
\hline Between Groups & 0.461 & 2 & 0.231 & 1.156 & 0.318 \\
Within Groups & 30.512 & 153 & 0.199 & & \\
Total & 30.973 & 155 & & & \\
\hline
\end{tabular}

According to the participants' results of the ANOVA test conducted with series mean in Table 5, no statistically significant difference was observed in terms of educational status.

Table 6. Results of ANOVA test conducted with series mean according to the sports experience

\begin{tabular}{llllll}
\hline Series Mean - Sports Experience & Sum of Squares & df & Mean Square & F & Sig. \\
\hline Between Groups & 0.609 & 3 & 0.203 & 1.017 & 0.387 \\
Within Groups & 30.363 & 152 & 0.200 & & \\
Total & 30.973 & 155 & & & \\
\hline
\end{tabular}

According to the participants' results of the ANOVA test conducted with series mean in Table 6, no statistically significant difference was observed in terms of sports experience.

Table 7. Results of t-test conducted with series mean according to sports branch

\begin{tabular}{llllllll}
\hline & Sports Branch & $\mathbf{N}$ & Mean & Std. Deviation & Std. Error Mean & F & p \\
\hline \multirow{2}{*}{ Series Mean } & Individual Sports & 90 & 2.387 & 0.421 & .044 & 3.026 & 0.084 \\
& Team Sports & 66 & 2.281 & 0.475 & .058 & & \\
\hline
\end{tabular}

According to the participants' results of the t-test conducted with series mean in Table 7, no statistically significant difference was observed in terms of the sports branch.

\section{Discussion and Conclusion}

Mental toughness consists of characteristics of individuals that enable them to deal with stress, failure, bad or difficult conditions without losing their self-confidence. The good news is that these characteristics can be developed. Call it tenacity, patience, determination or anything, the ability to deal with difficulties is a characteristic that enables successful people to overcome doubt, fear and anxiety and to achieve their long-term goals (Journal of Entrepreneur, 2019). In this study conducted within this scope, it was determined that the participating athletes, who practiced individual and team sports, included $100(64.1 \%)$ male athletes and 56 $(35.9 \%)$ female athletes. It was also determined that $48.1 \%$ of the participants were between 21 and 25 years old while $69.2 \%$ of them had undergraduate degrees in addition to $57.7 \%$ of the athletes who were interested in individual sports.

In Table 2, as a result of the t-test conducted with the series mean of the participants, it was observed that there was a statistically significant difference in terms of gender. As a result of the Tukey test conducted to determine this difference, it was determined that male athletes had higher levels of mental toughness compared to female athletes. It can be stated that this is because male athletes may not be affected by positive and negative situations they experience thanks to their nature, compared to female athletes. In the study conducted by Yarayan et al. on athletes in individual and team sports at an elite level, it was reported that male athletes had higher levels of mental toughness compared to female athletes, which is in line with our study (Yarayan et al., 2018).

According to the participants' results of the t-test conducted with series mean in Table 3 , no statistically significant difference was observed in terms of marital status.

According to the participants' results of the ANOVA test conducted with series mean in Table 4, no statistically significant difference was observed in terms of age. In the study conducted by Kalkavan et al. in 2017, it was reported that there was no statistically significant difference in terms of the variable of age, which is parallel to our study (Kalkavan et al., 2017). 
According to the participants' results of the ANOVA test conducted with series mean in Table 5, no statistically significant difference was observed in terms of educational status.

According to the participants' results of the ANOVA test conducted with series mean in Table 6, no statistically significant difference was observed in terms of sports experience. In the study conducted by Kayhan et al. on athletes, who practiced individual and team sports, in 2018, it was determined that there was not a significant difference between individuals in terms of individual sports and team sports (Kayhan et al., 2018).

In conclusion, of the athletes who participated in the study, it was observed that male athletes had higher levels of mental toughness compared to female athletes according to the gender variable. Furthermore, no significant differences were observed in terms of the variables of marital status, age, educational status, sports experience and sports branch.

\section{References}

Altintas, A. (2015). The role of dispositional flow, motivation level and goal orientation in determining mental toughness of athletes. Ph.D. Thesis. Ankara University, Institute of Health Sciences.

Bull, S. J., Shambrook, C. J., James, W., \& Brooks, J. E. (2005). Towards an understanding of mental toughness in elite English cricketers. Journal of Applied Sport Psychology, 17, 209-227. https://doi.org/10.1080/10413200591010085

Butt, J., Weinberg, R., \& Culp, B. (2010). Exploring mental toughness in NCAA Athletes. Journal of Intercollegiate Sport, 3(2), 316-332. https://doi.org/10.1123/jis.3.2.316

Clough, P. J., Earle, K., \& Sewell, D. (2002). Mental Toughness: The Concept and Its Measurement. In I. Cockerill (Ed.), Solutions in Sport Psychology (pp. 32-45). London: Thomson Publishing.

Cox, R. H. (2012). Sport Psychology. Concepts Applications (7th ed., pp. 297-298). New York.

Erdogan, N., \& Zihinsel, D. O. (2016). Mental Toughness Scale (MTS): The Study of Adaptation to Turkish, Validity and Reliability Study. International Journal of Science Culture and Sport September, 4(2).

Goldberg, A. S. (1992). Training the psychological dimension. Soccer Journal, 37(1), 58-60.

Gould, D., Hodge, K., Peterson, K., \& Petlichkoff, L. (1987). Psychological foundations of coaching: Similarities and differences among intercollegiate wrestling coaches. The Sport Psychologist, 1(4), 293-308. https://doi.org/10.1123/tsp.1.4.293

Gucciardi, D. F., Gordon, S., \& Dimmock, J. A. (2008). Towards an understanding of mental toughness in Australian football. Journal of Applied Sport Psychology, 20(3), 261-281. https://doi.org/10.1080/10413200801998556

Jacelon, C. S. (1997). The trait and process of resilience. Journal of Advanced Nursing, 25, 123-129. https://doi.org/10.1046/j.1365-2648.1997.1997025123.x

Jones, G. (2002). What is this thing called mental toughness? An investigation of elite sport performers. Journal of Applied Sport Psychology, 14(3), 205-218. https://doi.org/10.1080/10413200290103509

Jones, G., Hanton, S., \& Connaughton, D. (2007). A framework of mental toughness in the world's best performers. The Sport Psychologist, 21(2), 243-264. https://doi.org/10.1123/tsp.21.2.243

Journal of Entrepreneur. (2019, December). How to develop Mental Toughness. Retrieved from https://www.girisimcigazetesi.com/Zihinsel-Dayaniklilik-Nasil-Gelistirilir/158

Kalkavan, A., Acet, M., \& Cakir, G. (2017). Investigation of the Mental Endurance Levels of the Athletes Participating in the Table Tennis Championship of Universities in Turkey. International Journal of Science Culture and Sport, 5(4), 356-363. https://doi.org/10.14486/IntJSCS699

Kayhan, R. F., Hacicaferoglu, S., Aydogan, H., \& Erdemir, I., (2018). Examination of Mental Toughness Situations of Athletes Interested in Team and Individual Sports. Sportive View: Journal of Sports and Educational Sciences, 5(2), 55-64.

Luthar, S. S., Cichetti, D., \& Becker, B. (2000). The construct of resilience: A critical evaluation and guidelines for future work. Child Development, 71, 543-562. https://doi.org/10.1111/1467-8624.00164

Madrigal, L., Hamill, S., \& Gill, D. L. (2013). Mind over matter: The development of the mental toughness scale (MTS). Sport Psychologist, 27(1), 62-77. https://doi.org/10.1123/tsp.27.1.62

Selk, J. (2008). 10-minute toughness. McGraw-Hill Professional Publishing. 
Thelwell, R., Weston, N., \& Greenlees, I. (2005). Defining and understanding mental toughness within soccer. Journal of Applied Sport Psychology, 17(4), 326-332. https://doi.org/10.1080/10413200500313636

Yarayan, Y. E., Yildiz, A. B., \& Gulsen, D. B. (2018). Examination of Mental Toughness Levels of Individual and Team Sports Players at Elite Level According to Various Variables. The Journal of International Social Research, 11(57). https://doi.org/10.17719/jisr.2018.2509

\section{Copyrights}

Copyright for this article is retained by the author, with first publication rights granted to the journal.

This is an open-access article distributed under the terms and conditions of the Creative Commons Attribution license (http://creativecommons.org/licenses/by/4.0/). 